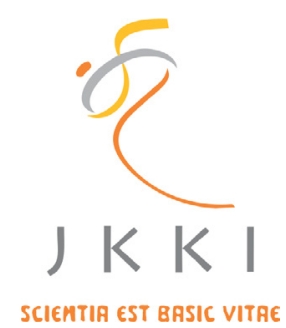

Jurnal Kedokteran dan Kesehatan Indonesia

Indonesian Journal of Medicine and Health

Journal homepage : www.journal.uii.ac.id/index.php/JKKI

\title{
Pulmonary tuberculosis in gestational patient with diabetes mellitus in Regional Public Hospital Dumai, Riau Province: a case report
}

Marsita Ayu Lestari*1, Amrizal Amir ${ }^{2}$

${ }^{1}$ Doctor Internsip in Regional Public Hospital Dumai, Riau, Indonesia

${ }^{2}$ Internist in Regional Public Hospital Dumai, Riau, Indonesia

Case Report

\begin{tabular}{|c|c|}
\hline & \\
\hline ARTICLE INFO & \multirow{6}{*}{$\begin{array}{l}\text { Diabetes mellitus increases the risk of pulmonary tuberculosis, whereas } \\
\text { pulmonary tuberculosis can aggravate glycemic control. Pulmonary } \\
\text { tuberculosis with diabetes mellitus in pregnancy is the complex problems } \\
\text { to concern about maternal and fetal complications. We report a 38-year- } \\
\text { old pregnant woman with a bloody cough for two days as a chief } \\
\text { complaint-volume } \pm 400 \text { millilitres in every cough. She also complained } \\
\text { a chronic cough, dyspnea, fatigue and weight loss approximately eight kg } \\
\text { in six months. Four months ago, she had a bloody cough one tablespoon. } \\
\text { The patient was hospitalized. The patient also felt thirsty and urinate } \\
\text { frequently, but she did not check the plasma glucose level. The patient } \\
\text { had a baby with weight birth } 4600 \text { gram, her son } 3 \text { year-old received } \\
\text { TB drugs and her sister with diabetes mellitus. In physical examination, } \\
\text { pale conjunctiva, and crackles in the lower region of the right lung and all } \\
\text { regions of the left lung. The results of laboratory are Hb } 10.7 \mathrm{~g} / \mathrm{dL} \text {, monosit } \\
\text { 11\%, ESR } 31 \% \text {, fasting plasma glucose } 137 \text { mg/dl, A1C } 7.3 \% \text {, spot } 3+\text { early } \\
\text { morning } 3+\text { spot } 2+\text { (sputum). A chest x-ray showed an infiltrate in the field } \\
\text { of the left lung. The patient had a pulmonary tuberculosis and diabetes } \\
\text { mellitus in pregnancy. The patient was cared by internist, obstetrician and } \\
\text { nutritionist.pulmonary tuberculosis and diabetes mellitus in pregnancy } \\
\text { can increase morbidity of maternal and fetal. Evaluation of plasma glucose } \\
\text { level was needed to determine diagnosis of type } 2 \text { diabetes mellitus or } \\
\text { gestational diabetes. Integrated management of internist, obstetrician } \\
\text { and nutritionist were needed to treat it. }\end{array}$} \\
\hline & \\
\hline & \\
\hline DOI : $10.20885 / J K K I . V o l 10 . I s s 2$. & \\
\hline & \\
\hline & \\
\hline
\end{tabular}

Diabetes melitus (DM) meningkatkan risiko tuberkulosis paru (TB paru), sedangkan TB paru dapat memperburuk kontrol glikemik. Tuberkulosis paru dengan DM pada kehamilan adalah masalah kompleks yang berkaitan dengan komplikasi ibu dan janin. Kami melaporkan wanita hamil berusia 38 tahun dengan keluhan utama batuk darah selama 2 hari dengan volume $\pm 400 \mathrm{~mL}$ setiap kali batuk. Pasien juga mengeluhkan batukyang lama, sesak napas, mudah lelah, dan penurunan berat badan sekitar $8 \mathrm{Kg}$ selama 6 bulan. Empat bulan yang lalu, pasien juga batuk darah sebanyak 1 sendok makan dan dirawat di rumah sakit. Pasien juga mengeluhkan sering haus dan buang air kecil, namun tidak memeriksa kadar glukosa plasmanya. Pasien mempunyai bayi dengan berat badan lahir 4.600 gram, anak laki-lakinya yang berusia 3 tahun telah menjalani pengobatan TB, dan saudara perempuannya mengidap DM. Pada pemeriksaan fisik, ditemukan konjungtiva pucat, dan ronki basah di basal paru kanan serta di seluruh lapangan paru kiri. Hasil pemeriksaan laboratorium didapatkan $\mathrm{Hb}$ 10,7 g/dL, monosit 11\%, LED 31\%, glukosa plasma puasa $137 \mathrm{mg} / \mathrm{dL}, \mathrm{A1C} 7,3 \%$, sputum SPS +3+3+2. Pada rontgen toraks ditemukan infiltrat di lapangan paru kiri. Pasien didiagnosis dengan TB paru dan DM pada kehamilan. Pasien dirawat oleh dokter spesialis penyakit 
dalam dan obstetri ginekologi serta ahli gizi. Tuberkulosis paru dan DM pada kehamilan dapat meningkatkan angka kesakitan pada ibu dan janin. Evaluasi kadar glukosa plasma dibutuhkan untuk menentukan apakah ini DM tipe 2 atau diabetes gestasional. Penatalaksanaan terpadu antara dokter spesialis penyakit dalam, dokter spesialis obstetri ginekologi, dan ahli gizi dibutuhkan pada kasus ini.

\section{INTRODUCTION}

Type 2 diabetes mellitus (T2DM) is a pandemic non-communicable disease in the world-wide. ${ }^{1}$ The prevalence of T2DM has been increasing in developing countries such as Indonesia. ${ }^{2}$ West Kalimantan, Maluku, and Riau have a higher prevalence than others. ${ }^{3}$ Diabetes mellitus increases the risk of many infectious diseases, including tuberculosis (TB). Many issues related to T2DM management during TB treatment remain unresolved. ${ }^{4,5}$ Pulmonary tuberculosis with diabetes mellitus in pregnancy is complicated. Therefore, integrated management should be done to concern about maternal and fetal complication.

\section{CASE REPORT}

A 38 -year-old pregnant woman with gestation 23 weeks, fourth pregnant with bloody cough for two days as a chief complaint. The volume \pm 400 millilitres in every cough. Blood was not mixed food. She denied melena. The patient also complained chronic cough, dyspnea, fatigue and weight loss approximately eight kilograms in six months. She denied dyspnea an effort, paroxysmal nocturnal dyspnea and orthopnea, fever, chest pain and night sweat.

Four months ago, she had a bloody cough one tablespoon. She was hospitalized and received cefotaxime injection 1 gram every 8 hours and ranitidine injection $50 \mathrm{mg}$ every 12 hours. The patient seeks treatment in the internal medicine polyclinic and received amoxicillin tablet 1500 $\mathrm{mg} /$ day in divided doses every 8 hours, ambroxol syrup $15 \mathrm{mg} / 5$ mlevery 8 hours, Paracetamol tablet $500 \mathrm{mg}$ every 8 hours s and tranexamic acid tablet every 8 hours $3 \times 1$.

For one year, she felt thirsty and urinate frequently. Feeling hungry was denied. The patient did not check the plasma glucose level. She had a baby with weight birth 4600 gram, her son 3-year-old received TB drugs and her sister with T2DM. She denied having an allergy, pulmonary TB, asthma, T2DM, hepatitis, consumed alcohol, consumed herb, smoked, and HIV. Her husband was an active smoker. There is no ventilation and well-lighting in house with accompanied densely populated settlements.

\section{Clinical findings}

The patient came with compos mentis condition, blood pressure was $120 / 90 \mathrm{mmHg}$, heart rate was 86 times per minute, respiration rate was 26 times per minute, temperature was $36.7^{\circ} \mathrm{C}$, body mass index was $23.1 \mathrm{~kg} / \mathrm{m} 2$ (weight $57 \mathrm{~kg}$, height $157 \mathrm{~cm}$ ), pale of both eyes conjunctiva, no increasing of JVP, heart examination finding was normal there was crackles in the lower region of right lung and all regions of left lung, high fundus uterus about 3 fingers above the umbilicus, fetal heart rate was 150 times per minute. No oedema in extremities.

\section{Diagnostic assessment}

Based onexamination findings: pale conjunctiva, crackles in the lower region of right lung and all regions of left lung, $\mathrm{Hb} 10.7 \mathrm{~g} / \mathrm{dL}$, monosit $11 \%$, ESR $31 \%$, fasting plasma glucose $137 \mathrm{mg} / \mathrm{dl}, \mathrm{A} 1 \mathrm{C} 7.3 \%$, spot 3+ early morning 3+ spot $2+$ (sputum), and infiltrate in the field of left lung.. Diagnostic challenges of this case arise with questions:Is it diabetes mellitus in pregnancy or gestational diabetes? Is it pulmonary tuberculosis to lead diabetes mellitus or diabetes mellitus to induce tuberculosis?

\section{Therapeutic intervention}

The patient was cared by internist, obstetrician and nutritionist. The integrated management of multi-specialist were needed to prevent maternal and fetal complications. Patient received medic-nutrition therapy, longacting insulin 0-0-8 IU subcutaneous, fixed drug combination (FDC) 1x3 tablets (rifampicine 150 $\mathrm{mg}$, Isoniazid $75 \mathrm{mg}$, pyrazinamide $400 \mathrm{mg}$, 
ethambutol hydrochloride $275 \mathrm{mg}$ ), IV line, codein $20 \mathrm{mg} 3 \times 1 / 2$ tablet, monitoring for vital signs and fetal heart rate, and the education of her diseases.

\section{Follow-up and Outcomes}

The patient was hospitalized from 26 April to 4 May 2014. The plasma glucose level every three days are $137 \mathrm{mg} / \mathrm{dL}, 195 \mathrm{mg} / \mathrm{dL}$, and 147 $\mathrm{mg} / \mathrm{dL}$. When she had a plasma glucose level about $195 \mathrm{mg} / \mathrm{dL}$, she received long-acting insulin 0-0-10 IU subcutaneous. The patient had been well for hospitalization and could be out-patient. The patient was educated about dietary treatment, long term insulin and FDC use, routine control, the prevention ofmaternal and fetal complications, and the examination of plasma glucose level pasca labour.

\section{DISCUSSION}

Type 2 diabetes mellitus (T2DM) is a collection of clinical symptoms characterized by hyperglycemia., ${ }^{2,6}$ Mechanism of hyperglycemia is regulated by eleven aggregates or well-known egregious eleven theory. There is eleven subject contributed to $\beta$ cell pancreas dysfunction. There are liver, muscle, fat tissue, brain, colon/biome, immune/inflammation, decreasing of insulin concentration, decreasing of incretin effect, $\alpha$ cell defect, stomach/ intestine and kidney. ${ }^{7}$
The criteria of diagnoses for DM in pregnancy is fasting plasma glucose level $\geq 126 \mathrm{mg} / \mathrm{dL}$ or plasma glucose after 2-hour oral glucose tolerance test 75 gram $\geq 200 \mathrm{mg} / \mathrm{dL}$ or random plasma glucose with classic symptom $\geq 200 \mathrm{mg}$ / dL. Criteria diagnoses for gestational diabetes is fasting plasma glucose level $92-125 \mathrm{mg} /$ $\mathrm{dL}$, plasma glucose after 1-hour oral glucose tolerance test 75 gram $180 \mathrm{mg} / \mathrm{dL}$ or plasma glucose after 2-hour oral glucose tolerance test 75 gram $153-199 \mathrm{mg} / \mathrm{dL}^{6}{ }^{6}$

Diabetes mellitus increases the risk of TB and aggravates the patient's condition. Pulmonary TB can aggravate glycemic control. Pulmonary TB with DM in pregnancy is complex problems. The criteria diagnoses for pulmonary TB based on International Standards for Tuberculosis Care (ISTC). ${ }^{8,9}$

In this case, diagnosis pulmonary TB based on symptom (bloody cough for 2 days, its volume \pm 400 mililiter, long time for productive cough, fever, fatigue, weight loss and dyspnea), risk factors (there is no ventilation and well-lighting in house, a high prevalence of pulmonary TB in Indonesia), clinical findings (crackles in the lower region of right lung and all regions of left lung), the result of sputum test (spot $3+$ early morning $3+$ spot $2+$ ), chest $x$-ray (infiltrate in the field of left lung). Figure 1 displays chest $\mathrm{x}$-ray of this patient.

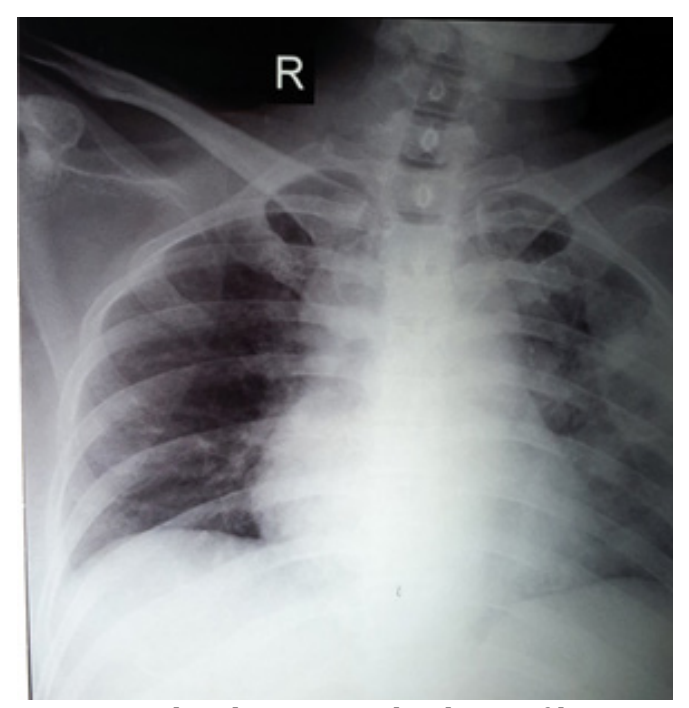

Figure 1 . The chest $\mathrm{x}$-ray displays infiltrate in the field of left lung 
Diabetes mellitus in pregnancy based on the symptom (thirsty and frequently urinate for a year), risk factors (baby with weight birth 4600 gram, her sister had DM), and the results of laboratory (fasting plasma glucose $137 \mathrm{mg} / \mathrm{dl}$, A1C 7.3\%). To determine "Did the patient have DM in pregnancy or gestational diabetes?" The patient was educated to check plasma glucose level after labour. When it was found normal, she had gestational diabetes. When it was found hyperglycemia, she had T2DM.

The patient was treated with the antituberculosis drug, except streptomycin. Integrated management of internist, obstetrician and nutritionist had been done to treat her diseases and prevent maternal complications such as pre-eclampsia, the complication of labour and risk of T2DM. Whereas fetal complications such as giant baby, premature, and hypoglycemia.

The patient received dietary treatment and long-acting insulin. The fasting plasma glucose level $\leq 105 \mathrm{mg} / \mathrm{dL}$ and 2 hours after prandial of plasma glucose level $\leq 120 \mathrm{mg} / \mathrm{dL}$ as the goal of treatment. The limitations of this case are to determine diagnosis T2DM or gestational diabetes. We did not know that is it T2DM or gestational diabetes. We did not know that patient had diabetes before her pregnancy or during pregnancy. Because patient did not check plasma glucose before she had pregnant, she was educated to control plasma glucose after she had childbirth.

\section{CONCLUSION}

Integrated management of internist, obstetrician and nutritionist were needed to avoid morbidity of maternal and fetal. The kind preparation of pregnancy is to screen risk factors for T2DM and pulmonary TB. When she has risk factors of DM, she will check the plasma glucose level in the first visitation of antenatal care. Evaluate the plasma glucose level after childbirth to determine the diagnosis of T2DM or gestational diabetes.

\section{Disclosures}

The case presented in this manuscript was presented as poster presentation at the Jakarta Internal Medicine in Daily Practice in 2017.

\section{CONFLICT OF INTEREST}

None declare.

\section{Acknowledgement}

None declare.

\section{REFERENCES}

1. U.S. Department of Health and Human Services Food and Drug Administration Center for Drug Evaluation and Research (CDER). Guidance for Industry diabetes mellitus evaluating cardiovascular risk in new antidiabetic therapies to treat type 2 diabetes. Clinical/Medical. 2008;1-5.

2. Suyono S. Diabetes melitus di Indonesia. In: Sudoyo AW, Setiyohadi B, Alwi I, Simadibrata M, Setiati S, editor. Ilmu penyakit dalam. V. Jakarta: Interna Publishing; 2009.

3. Depkes RI. Profil kesehatan Indonesia 2008. Jakarta:Departemen Kesehatan Republik Indonesia. 2009.

4. Critchley JA, Restrepo BI, Ronacher K, Kapur A, Bremer AA, Schlesinger LS, et al. Defining a research agenda to address the converging epidemics of tuberculosis and diabetes. Chest [Internet]. 2017;152(1):165-73. Available from: https://linkinghub.elsevier. com/retrieve/pii/S0012369217307304

5. Riza AL, Pearson F, Ugarte-gil C, Alisjahbana B, van de Vijver S, Panduru NM, et al. Clinical management of concurrent diabetes and tuberculosis and the implications for patient services. 2014;2(9):740-53.

6. Adam J, Purnamasari D. Diabetes mellitus gestasional. In: Sudoyo AW, Setiyohadi B, Alwi I, Simadibrata M, Setiati S, editor. Ilmu penyakit dalam. V. Jakarta: Interna Publishing; 2009. p. 1952-5.

7. Schwartz SS, Epstein S, Corkey BE, Grant SFA, Gavin JR, Aguilar RB. The time is right for a new classification system for diabetes: Rationale and implications of the $\beta$-cell-centric classification schema. Diabetes Care. 2016;39(2):179-86.

8. Amin Z, Bahar A. Tuberkulosis paru. In: Su- 
doyo AW, Setiyohadi B, Alwi I, Simadibrata M, Setiati S, editor. Ilmu penyakit dalam. V. Jakarta: Interna Publishing; 2009. p. 223047.

9. Persatuan Dokter Paru Indonesia. Pedoman diagnosis dan penatalaksanaan tuberkulosis di Indonesia (Konsensus TB). 2009;155 . 